\title{
Faktor Penentu Perilaku Impulsive Buying Pada Fashion Business Di Kota Bandung
}

\author{
Oleh: \\ Novia MH \& Harmon \\ Politeknik Negeri Bandung
}

\begin{abstract}
Impulsive buying behavior is behavior that appears suddenly and without planned in advance by the consumer while shopping. The impulsive behavior arise because of the factors that encourage consumers to shop beyond of the plan. From a business standpoint, this behavior will have a positive impact, by setting a good marketing strategy and understand the factors that cause this behavior it will be the manager of the business will get a large income. This study discusses the factors that lead to impulsive behavior with using descriptive analysis method. By using questionnaires distributed to a sample of consumers factory outlet with 100 respondents then processed using SPSS 16.0 will produce a mean as a reference level of each indicator. The factors that have been tested, the indicators store atmosphere has the highest mean value, which means that the store atmosphere factors which are elements of the store environment is a dominated factor that cause of impulsive buying. Expected benefits of this research can be perceived by various parties especially for business managers and readers as consumers, in order to be wise addressing the increasingly modern market developments from time to time.
\end{abstract}

Keywords: Impulsive Buying, fashion business, factory outlet, store atmosphere

\section{Latarbelakang}

Ada perilaku yang berbeda dari konsumen dalam berbelanja di masing-masing wilayah. Khusus konsumen Indonesia, kadang-kadang lebih emosional dalam membuat proses keputusan untuk memilih dan membeli suatu produk. Pengaruh lain yang unik adalah referensi dalam hal pembelian, seperti: pendapat atau opini para pemimpin cukup besar, terutama pada suku Jawa, Madura dan Sunda. Konsumen akan percaya pada apa yang dipilih dan disarankan oleh para ulama dan toko agama dalam memilih produk-produk tertentu. Saran dan keteladanan para ulama menjadi bagian yang dipertimbangkan dalam membuat evaluasi terhadap pembelian suatu produk. Demikian pula, untuk beberapa suku dimana tradisi adatnya masih kuat seperti suku Bali, para pemimpin adat ini jugalah yang menjadi opinion leader saat mereka memutuskan untuk membeli dan pergi ke pusat perbelanjaan.

Konsumen Indonesia tidak banyak mencerna informasi dalam mengambil keputusan pembelian). Salah satu kebiasaan konsumen Indonesia lainnya adalah tidak memiliki rencana yang pasti tentang produk apa saja yang akan mereka beli (Sunyoto, 2012)

Studi yang dilakukan Nielsen melalui wawancara tatap muka dengan 1.804 responden, dengan belanja rumah tangga lebih dari 1,5 juta perbulan di Jakarta, Bandung, Surabaya, Makasar dan Medan, 21\% pebelanja mengaku tidak pernah membuat rencana belanja. Angka ini jauh lebih tinggi dari angka tahun 2003 yang hanya 11\%. Dalam studi tahun 2011, 39\% pebelanja yang membuat daftar belanja pun mengaku selalu membeli barang-barang diluar daftar saat berbelanja.

Dalam kaitan ini, khusus untuk pembelanjaan fashion hasil survey sementara pada 23 konsumen Factory Outlet (FO) di kota Bandung, 21 diantaranya pernah melakukan impulsive buying saat memutuskan untuk pergi ke FO. Mereka memutuskan membeli didasarkan rasa suka karena model yang menarik dan cocok saat digunakan. Lima belas dari 21 konsumen mengaku bahwa mereka pernah pergi ke FO tanpa rencana sebelumnya, datang begitu saja dengan tujuan untuk melihat-lihat meskipun pada akhirnya mereka membeli suatu produk 
karena ketertarikan saat melihatnya. Sedangkan 18 dari 21 konsumen pernah membeli produk lain diluar dari apa yang mereka rencanakan sebelumnya, hal tersebut hanya didasarkan atas ketertarikan dan kemampuan dana mereka membeli produk.

Jika dilihat dari sisi konsumen, hal demikian lambat laun bisa menjadi masalah bagi perekonomiannya, efeknya konsumen yang menunjukkan perilaku impulsif akan merasa ingin membeli produk lain diluar rencana mereka sebelumnya. Konsumen akan semakin konsumtif jika perilaku seperti ini terus dipelihara tanpa sadar. Oleh karena itu konsumen harus mengetahui penyebab timbulnya perilaku impulsif ini. Namun, jika kita melihat dari segi penjual, perilaku ini justru akan berdampak baik pada pendapatan penjual. Strategi pemasaran dan cara menciptakan suasana toko yang baik akan menarik perhatian konsumen melakukan pembelian produk tidak terencana tersebut.

Perilaku Impulsive Buying secara tidak sadar sering dilakukan oleh konsumen Indonesia, khususnya warga kota Bandung. Perilaku ini didorong oleh faktor-faktor yang berbeda-beda, seperti: faktor situasional (store environment, ketersediaan waktu, ketersediaan uang), person related (informasi dan pengalaman, kredibilitas, daya tarik, reference group, sifat produk). Faktor-faktor tersebut dijadikan fokus kajian untuk meneliti perilaku konsumen factory outlet di Kota Bandung.

\section{Tujuan Penelitian}

Penelitian ini bertujuan mengungkap faktor penentu impulsive buying dari konsumen factory outlet yang ada di Kota Bandung.

\section{Perilaku Impulsive Buying}

Menurut Padmono, (2011) Impulsif merupakan istilah psikologi yang menunjukkan bahwa individu yang terlibat dan melibatkan diri dalam bentuk reaksi perilaku yang dilakukan tanpa berpikir (tanpa merefleksi secara cukup) sehingga orang itu tidak mampu menahan untuk merespon balik. Individu ini tidak mampu mengendalikan hasrat dirinya dalam merespon rangsang. Individu ini tak sadar lebih mengedepankan perintah atau naluri semata. Mereka terdorong dan ingin berbuat atau ada kecenderungan yang mengarah pada suatu perbuatan. Utami (2010: 50) mengingatkan pembelian impulsif terjadi ketika konsumen tiba-tiba mengalami keinginan yang kuat dan kukuh untuk membeli secepatnya.

Hakekat impulsive buying atau unplanned buying adalah perilaku yang muncul pada konsumen secara tiba-tiba pada saat melakukan pembelian tanpa merencanakan terlebih dahulu. Perilaku ini bisa disebabkan oleh faktor yang berasal dari konsumen maupun dari pasar itu sendiri.

\section{Tipe-tipe perilaku Impulsive Buying}

Ada beberapa tipe dari pembelian tidak terencana (impulsive buying) menurut Loudon, dkk. dalam I'sana (2013):

1. Pure Impulse (Impuls murni). Tindakan pembelian sesuatu karena alasan menarik biasanya ketika suatu pembelian terjadi karena loyalitas terhadap merek atau perilaku pembelian yang telah biasa dilakukan.

2. Reminder Impulse (impuls pengingat). Pembeli melihat produk tersebut dan diingatkan bahwa persediaan di rumah perlu ditambah atau telah habis.

3. Suggestion Impulse (impuls saran). Suatu produk yang ditemui konsumen untuk pertamakali akan menstimulasi keinginan untuk mencobanya.

4. Planned Impulse (impuls terencana). Aspek perencanaan dalam perilaku ini menunjukkan respons konsumen terhadap beberapa insentif special untuk membeli unit yang tidak diantisipasi. Impuls ini biasanya distimulasi oleh pengumuman penjualan kupon, potongan kupon, atau penawaran yang menggiurkan lainnya. 
Selain tipe-tipe di atas, Impulsive Buying juga memiliki karakteristik. Rook dan Fisher dalam Putra (2014), menguraikan bahwa impulse buying memiliki beberapa karakteristik, yaitu sebagai berikut :

1. Spontanitas. Pembelian ini tidak diharapkan, ia memotivasi konsumen untuk membeli sekarang, sering sebagai respons terhadap stimulasi visual yang langsung ditempat penjualan.

2. Kekuatan, kompulsi, dan intensitas. Adanya motivasi untuk mengesampingkan semua yang lain dan bertindak seketika atau memutuskan seketika.

3. Kegairahan dan stimulasi. Merupakan desakan yang dirasakan seseorang secara mendadak untuk membeli, sering juga disertai emosi yang dicirikan sebagai "menggairahkan" atau "menggetarkan".

4. Ketidakpedulian akan akibat. Adalah desakan untuk membeli segera, seseorang merasakan begitu sulit menolaknya, sehingga akibat yang bisa menimbulkan hal-hal negatif diabaikannya.

\section{Faktor-faktor yang menimbulkan perilaku Impulsive Buying}

Menurut Verplanken dan Herabadi dalam Tenadidjaja (2007), terdapat dua variabel yang mempengaruhi pembelanjaan impulsif, antara lain:

\section{Variabel Situasional}

Variabel situasional ini adalah variabel yang memicu pembelian impulsif konsumen yang terkait dengan lingkungan toko (store environment), ketersediaan waktu, dan ketersediaan uang.

\section{a. Lingkungan Toko (Store Environment)}

Adalah pengaruh keadaan toko atau lingkungan toko, ia merupakan kombinasi dari karakteristik fisik toko, seperti arsitektur, tata letak, penanda/label, pemajangan warna, pencahayaan, temperatur, musik, serta aroma, yang secara menyeluruh akan menciptakan citra dalam benak konsumen (Levy dan Weitz, dalam Putra, 2014).

Melalui elemen-elemen lingkungan toko, para penjual memunculkan stimulistimuli pemicu pembelian tidak terencana atau pembelian impulsive berupa:

1) Store Image. Store Image adalah elemen terpenting bagi seorang penjual menarik dan memenuhi kepuasan konsumen, Store Image menggambarkan apa yang dilihat dan dirasakan oleh konsumen. Baik atau tidaknya citra toko tidak dapat konsumen nilai dari penampilan interior maupun eksterior toko.

2) Store Atmosphere. Store Atmosphere merupakan kombinasi dari pesan secara fisik yang telah direncanakan.Store Atmosphere digambarkan sebagai perubahan perancangan lingkungan pembelian yang menghasilkan efek emosional khusus dan menyebabkan konsumen melakukan tindakan pembelian (Gilbert dalam Suprapto, 2015). Atmosfir toko yang menyenangkan seharusnya memiliki atribut-atribut yang menarik perhatian kelima panca indera manusia, seperti pada penglihatan, penciuman, pendengaran, peraba dan perasa.

3) Store Theatrics. Sebuah toko bukan hanya sekedar menjual produk untuk dibeli oleh konsumen, sebuah toko hendaknya mampu memberikan kepuasan bagi konsumen. Sebuah toko hendaknya mampu memberikan dan menunjukkan kepada konsumen bahwa toko mereka adalah toko yang berbeda dari toko lainnya, sehingga konsumen tertarik berkunjung dan melakukan pembelian pada toko tersebut karena konsumen merasa toko yang bersangkutan unik serta mampu memberikan pertunjukan produk bagi konsumen.

Elemen-elemen di dalam toko yang menyenangkan dapat menumbuhkan perasaan yang positif pada konsumen. Hasil penelitian Tenda dkk dalam Putra(2014) 
memberikan bukti empiris bahwa "semakin menunjangnya store environment semakin tinggi pula keputusan konsumen untuk melakukan impulse buying".

b. Ketersediaan Waktu (Time Available)

Beatty dan Ferrel (dalam Asterrina, 2013), time available mengacu pada waktu yang tersedia bagi individu untuk berbelanja. Tekanan waktu bisa mengurangi impulse buying, sebaliknya ketersediaan waktu dan sifat hedonis untuk berbelanja mendorong orang melakukan aktivitas pencarian dalam lingkungan ritel dan mengakibatkan timbulnyaimpulse buying(Iyer, 1989; Park, 2006; Yu and Bastin, 2010). Individu dengan lebih banyak waktu yang tersedia akan melakukan pencarian lagi.

c. Ketersediaan Uang (Money Available)

Money available mengacu pada jumlah anggaran atau dana ekstra yang dimiliki oleh seseorang yang harus dikeluarkan pada saat berbelanja. Ia menghubungkan variabel ketersediaan uang secara langsung dengan impulse buying karena hal tersebut dinilai menjadi fasilitator terjadinya pembelian terhadap suatu objek. (Beatty dan Ferrel, dalam Asterrina, 2013).

\section{Variabel Person-Related}

Grup referensi yang sangat dipercaya cenderung memiliki pengaruh informasional yang cukup besar pada konsumen. Grup ini bisa memengaruhi perilaku dan gaya hidup seseorang, mereka mempengaruhi pilihan produk serta merek yang akan dibeli konsumen. Sementara itu Kotler (dalam Sianturi, 2012)mengingatkan bahwa kelompok referensi adalah seseorang atau sekelompokorang yang memengaruhi perilaku individu secara signifikan, dapat berupa artis,atlet, tokoh politik, kelompok musik, dan partai politik.

Tingkat pengaruh yang diberikanreference grouppada perilaku perorangan biasanya tergantung pada sifat individu, produk dan faktor sosial tertentu. Dampak reference grouppada perilaku konsumen antara lain (Schiffman dan Kanuk, 2008):

a. Informasi dan Pengalaman.

Orang yang mempunyai pengalaman langsung dengan suatu produk/jasa ataudengan mudah dapat memperoleh informasi lengkap mengenai hal itu.

b. Kredibilitas, Daya Tarik, dan Kekuatan Reference Group

Kelompok rujukan yang dirasakan kredibel, menarik, atau berkuasa dapat menimbulkan perubahan sikap dan perilaku konsumen. Jika para konsumen sangat memperhatikan penerimaan dan persetujuan orang-orang yang disukai, yaitu orangorang yang ingin mereka tiru atau yang memberikan mereka status atau berbagai manfaat lain, mereka mungkin menggunakan produk dengan merek yang digunakan orang-orang yang mereka tiru.

c. Sifat Produk yang Menonjol

Produk yang menonjol secara visual adalah produk yang mencolok dandiperhatikan (barang mewah). Produk yang menonjol secara verbal bisadigambarkan dengan mudah dibandingkan dengan yang lain.

Melihat pendapat di atas, diperoleh informasi bahwa faktor-faktor tersebut di atas adalah pemicu terjadinya perilaku impulsive buying, inidilihat dari sisi konsumen, produk dan pemasaran. Jika mengacu pada uraian di atas, benang merah karakteristik konsumen merupakan faktor internal yang terdiri dari kepribadian konsumen berupa gaya hidup, kesenangan belanja, ketersediaan waktu dan ketersediaan uang. Sedangkan karakteristik produk dan pemasaran adalah faktor yang menyebabkan timbulnya perilaku impulsive buying yang berasal dari luar atau eksternal. 


\section{METODE PENELITIAN}

Dalam penelitian ini metode yang digunakan adalah metode penelitian deskriptif dengan pendekatan kuantitatif. Menurut Sugiyono (2012:22) metode deskriptif adalah metode yang digunakan untuk menggambarkan atau menganalisis suatu hasil penelitian tetapi tidak digunakan untuk membuat kesimpulan yang lebih luas. Dengan menggunakan metode penelitian deskriptif, maka akan diperoleh penjelasan-penjelasan mengenai faktor-faktor penyebab pembelian impulsif pada konsumen FO di kota Bandung.

\section{Populasi dan Sampel}

1. Populasi meliputi keseluruhan dari karakteristik atau sifat yang dimiliki oleh obyek/subyek penelitian. Berdasarkan pengertian tersebut, maka populasi dari penelitian ini adalah seluruh konsumen FO di kota Bandung.

2. Sampel, karena populasi dari penelitian ini tidak diketahui jumlahnya yaitu konsumen factory outlet di kota Bandung, maka untuk menentukan sampel yang akan digunakan penulis mengacu pada pendapat Frankel dan Wallen (1993:92), mereka menyarankan besar sampel minimum untuk penelitian deskriptif sebanyak 100 orang.

\section{Operasional Variabel}

Variabel penelitian dan indikator penelitian ini seperti terlihat pada tabel dibawah ini:

Tabel 1: Operasionalisasi Variabel

\begin{tabular}{|c|c|c|c|}
\hline Variabel & Indikator & Pernyataan & $\begin{array}{c}\text { No. } \\
\text { Pernyataan }\end{array}$ \\
\hline \multirow[t]{9}{*}{$\begin{array}{l}\text { Impulsive } \\
\text { Buying }\end{array}$} & \multirow{3}{*}{ Store Image } & $\begin{array}{l}\text { Saya tertarik belanja di FO karena desain } \\
\text { bangunannya modern }\end{array}$ & 1 \\
\hline & & $\begin{array}{l}\text { FO yang saya kunjungi menyediakan produk } \\
\text { yang berkualitas }\end{array}$ & 2 \\
\hline & & FO menjaga kebersihan toko & 3 \\
\hline & \multirow{3}{*}{$\begin{array}{c}\text { Store } \\
\text { Atmosphere }\end{array}$} & $\begin{array}{l}\text { Saya tertarik belanja di FO karena suasana } \\
\text { toko yang nyaman }\end{array}$ & 4 \\
\hline & & $\begin{array}{l}\text { Pengaturan tata letak fisik toko tertata } \\
\text { dengan baik sehingga memudahkan saya } \\
\text { untuk menemukan barang yang saya cari }\end{array}$ & 5 \\
\hline & & $\begin{array}{l}\text { Pencahayaan pada FO sudah baik sehingga } \\
\text { memudahkan saya dalam memilih produk. }\end{array}$ & 6 \\
\hline & \multirow{3}{*}{$\begin{array}{l}\text { Store } \\
\text { Theatrics }\end{array}$} & $\begin{array}{l}\text { Penggunaan Mannequin (boneka panjangan) } \\
\text { memudahkan saya untuk melihat model } \\
\text { pakaian }\end{array}$ & 7 \\
\hline & & $\begin{array}{l}\text { FO mendekor ruangan sesuai dengan tema- } \\
\text { tema tertentu (seperti saat hari kemerdekaan, } \\
\text { Lebaran, Imlek, Natal, dan sebagainya) }\end{array}$ & 8 \\
\hline & & $\begin{array}{l}\text { FO memiliki program promosi pada event- } \\
\text { event tertentu untuk meningkatkan frekuensi } \\
\text { kunjungan konsumen (tidak valid) }\end{array}$ & 9 \\
\hline
\end{tabular}




\begin{tabular}{|c|c|c|}
\hline \multirow{3}{*}{$\begin{array}{l}\text { Ketersediaan } \\
\text { Waktu }\end{array}$} & $\begin{array}{l}\text { Saya memiliki banyak waktu untuk } \\
\text { berbelanja }\end{array}$ & 10 \\
\hline & $\begin{array}{l}\text { Saya bisa pergi lebih dari setengah hari } \\
\text { hanya untuk berbelanja }\end{array}$ & 11 \\
\hline & $\begin{array}{l}\text { Saya menyempatkan diri untuk berbelanja } \\
\text { sesibuk apapun saya }\end{array}$ & 12 \\
\hline \multirow{3}{*}{$\begin{array}{l}\text { Ketersediaan } \\
\text { Uang }\end{array}$} & Anggaran saya ketat untuk berbelanja & 13 \\
\hline & $\begin{array}{l}\text { Saya memiliki uang lebih untuk melakukan } \\
\text { pembelian pakaian yang tidak direncanakan }\end{array}$ & 14 \\
\hline & $\begin{array}{l}\text { Saya memiliki anggaran khusus setiap bulan } \\
\text { untuk membeli produk fashion }\end{array}$ & 15 \\
\hline \multirow{2}{*}{$\begin{array}{l}\text { Informasi } \\
\text { dan } \\
\text { Pengalaman }\end{array}$} & $\begin{array}{l}\text { Saya akan membeli produk dengan merek } \\
\text { yang sama jika saya merasa puas dengan } \\
\text { produk tersebut sebelumnya }\end{array}$ & 16 \\
\hline & $\begin{array}{l}\text { Saya sudah mengetahui informasi tentang } \\
\text { merek produk yang saya beli berdasarkan } \\
\text { pengalaman pribadi }\end{array}$ & 17 \\
\hline \multirow{3}{*}{$\begin{array}{c}\text { Kredibilitas, } \\
\text { Daya Tarik, } \\
\text { dan } \\
\text { Kekuatan } \\
\text { Reference } \\
\text { Group }\end{array}$} & $\begin{array}{l}\text { Saya tertarik membeli produk dengan merek } \\
\text { terkenal }\end{array}$ & 18 \\
\hline & $\begin{array}{l}\text { Saya mendapatkan rekomendasi suatu } \\
\text { produk dari orang-orang yang saya kenal }\end{array}$ & 19 \\
\hline & $\begin{array}{l}\text { Saya tertarik membeli produk fashion model } \\
\text { terbaru }\end{array}$ & 20 \\
\hline \multirow{2}{*}{$\begin{array}{l}\text { Sifat Produk } \\
\text { yang } \\
\text { Menonjol }\end{array}$} & $\begin{array}{l}\text { Saya membeli produk fashion yang memiliki } \\
\text { asesoris tambahan }\end{array}$ & 21 \\
\hline & Saya membeli produk fashion yang unik & 22 \\
\hline
\end{tabular}

\section{ANALISIS DAN PEMBAHASAN}

1. Uji Validitas

Untuk mengetahui valid tidakya instrumen/item yang digunakan sebagai alat ukur penelitian adalah dengan melihat kolom correlated item total correlation. Untuk setiap item, nilai minimun yang ditetapkan adalah $\geq 0,3$.

Uji Validitas dilakukan pada 30 responden, dari hasil uji validitas yang telah dilakukan terdapat dua item yang memiliki nilai dibawah 0,3 artinya kedua item tersebut tidak valid dan tidak akan digunakan pada tahap selanjutnya, yaitu item 9 dan item13.

2. Uji Reliabilitas

Berikut adalah output dari uji reliabilitas menggunakan aplikasi SPSS 16.

\begin{tabular}{|c|c|}
\multicolumn{2}{c}{ Reliability Statistics } \\
\begin{tabular}{|c|c|}
\hline Cronbach's Alpha & N of Items \\
\hline .865 & 22 \\
\hline
\end{tabular}
\end{tabular}


Dari hasil uji reliabilitas yang telah dilakukan, nilai yang ditunjukan pada kolom Cronbach's Alpha lebih $\geq 0,70$ yaitu 0,865 yang artinya bahwa instrumen dan data yang yang diperoleh reliable atau layak digunakan pada penelitian ini.

\section{Indikator Store Image}

Tabel 2: Tanggapan Responden Indikator Store Image

\begin{tabular}{|c|l|c|c|}
\hline No. & \multicolumn{1}{|c|}{ Pernyataan } & $\begin{array}{c}\text { Rata-rata } \\
\text { (Mean) }\end{array}$ & $\begin{array}{c}\text { Std. } \\
\text { Deviasi }\end{array}$ \\
\hline 1 & $\begin{array}{l}\text { Saya tertarik belanja di FO karena desain } \\
\text { bangunannya modern (image1) }\end{array}$ & 3,75 & 0,98 \\
\hline 2 & $\begin{array}{l}\text { FO yang saya kunjungi menyediakan } \\
\text { produk yang berkualitas (image2) }\end{array}$ & 4,00 & 0,73 \\
\hline 3 & FO menjaga kebersihan toko (image3) & 4,20 & 0,63 \\
\hline \multicolumn{2}{|l|}{ Rata-rata Indikator Store Image } & 3,98 & 0,78 \\
\hline
\end{tabular}

Pada indikator Store Image terdapat tiga pernyataan,ketiga pernyataan tersebut menghasilkan total mean sebesar 3,98 hal tersebut membuktikan bahwa indikator Store Image berada pada kategori tinggi. Maknanya adalah bangunan yang modern, pengadaan produk dengan kualitas baik serta kebersihan toko menjadikan faktor pendorong konsumen berbelanja diluar rencana mereka. Jika pengelolaan store image lebih diperhatikan lagi, nilai untuk indikator ini akan meningkat menjadi sangat tinggi.

Standar deviasi yang tidak besar karena tidak lebih dari 20\% dari mean, menunjukkan variansi yang kecil (Santoso dalam Azizah, 2015). Dari ketiga pernyataan yang di ajukan menghasilkan standar deviasi sebesar 0,78 atau sama dengan $19.59 \%$, angka tersebut tidak melebihi $20 \%$ dari mean. Artinya keragaman jawaban untuk indikator store image adalah kecil atau sebagian besar responden menjawab dengan tanggapan yang hampir sama.

\section{Indikator Store Atmosphere}

Tabel 3: Tanggapan Responden Indikator Store Atmosphere

\begin{tabular}{|c|l|c|c|}
\hline No. & \multicolumn{1}{|c|}{ Pernyataan } & $\begin{array}{c}\text { Rata-rata } \\
\text { (Mean) }\end{array}$ & $\begin{array}{c}\text { Std. } \\
\text { Deviasi }\end{array}$ \\
\hline 1 & $\begin{array}{l}\text { Saya tertarik belanja di FO karena suasana toko yang nyaman } \\
\text { (atmosphere4) }\end{array}$ & 3,94 & 0,81 \\
\hline 2 & $\begin{array}{l}\text { Pengaturan tata letak fisik toko tertata dengan baik sehingga } \\
\text { memudahkan saya untuk menemukan barang yang saya cari } \\
\text { (atmosphere5) }\end{array}$ & 4,00 & 0,73 \\
\hline 3 & $\begin{array}{l}\text { Pencahayaan pada FO sudah baik sehingga memudahkan saya } \\
\text { dalam memilih produk. (atmosphere6) }\end{array}$ & 4,05 & 0,64 \\
\hline \multicolumn{1}{|c|}{ Rata-rata Indikator Store Atmosphere } & 4,00 & 0,73 \\
\hline
\end{tabular}

Pada indikator Store Atmospherememiliki tiga pernyataan, dari ketiga pernyataan, total meanyang dihasilkan sebesar 4,00 hal tersebut membuktikan bahwa indikator store atmosphere berada pada kategori tinggi. Artinya suasana toko yang nyaman, pencahayaan yang baik serta pengaturan tata letak ruangan yang teratur menjadikan faktor pendorong konsumen untuk berbelanja diluar rencana mereka.

Standar deviasi yang diperoleh untuk indikator ini, masih dibawah $20 \%$ dari meanatau variansinya kecil (Santoso dalam Azizah, 2015). Jika dilihat dari tabel diatas,ketiga pernyataan itu menghasilkan standar deviasi sebesar0,73atau sama dengan 18,18\%, angka demikian tidak melebihi $20 \%$ dari mean. Maknanya keragaman jawaban untuk indikator store 
ttmosphere adalah kecil atau sebagian besar responden menjawab dengan tanggapan yang relatif sama.

\section{Indikator Store Theatrics}

Tabel 4: Tanggapan Responden Indikator Store Theatrics

\begin{tabular}{|c|l|c|c|}
\hline No. & \multicolumn{1}{|c|}{ Pernyataan } & $\begin{array}{c}\text { Rata-rata } \\
\text { (Mean) }\end{array}$ & $\begin{array}{c}\text { Std. } \\
\text { Deviasi }\end{array}$ \\
\hline 1 & $\begin{array}{l}\text { Penggunaan Mannequin (boneka panjangan) memudahkan saya } \\
\text { untuk melihat model pakaian (theatrics7) }\end{array}$ & 3,89 & 0,85 \\
\hline 2 & $\begin{array}{l}\text { FO mendekor ruangan sesuai dengan tema-tema tertentu } \\
\text { (seperti saat hari kemerdekaan, Lebaran, Imlek, Natal, dan } \\
\text { sebagainya) (theatrics8) }\end{array}$ & 3,99 & 0,73 \\
\hline \multicolumn{2}{|l|}{ Rata-rata Indikator Store Theatrics } & 3,94 & 0,79 \\
\hline
\end{tabular}

Berdasarkan tabel 4 pada indikator store theatrics dengan pernyataan theatrics7menunjukkan mean sebesar3,89, dan theatrics8sebesar 3,99. Apabila mengacu pada rentang nilai, ketiga pernyataan tersebut berada pada rentang 3,41-4,20 dan termasuk kategori dengan rentang nilai tinggi.

Dari kedua pernyataan indikator store theatrics, total mean sebesar 3,94 hal tersebut membuktikan bahwa indikator store theatrics berada pada kategori tinggi. Artinya bahwa penggunaan mannequin dan dekorasi toko menggunakan tema yang sesuai dengan hari-hari besar menjadikan faktor pendorong konsumen untuk berbelanja diluar rencana mereka karena konsumen akan tertarik untuk datang ke toko setelah melihat toko tersebut memiliki pertunjukkan yang dapat menarik perhatian konsumen.

Standar deviasi yang yang diperoleh tidak lebih dari $20 \%$ dari mean, menunjukkan variansi yang kecil. Jika dilihat dari tabel 4, pernyataan theatrics7 memiliki standar deviasi sebesar 0,85, dan theatrics8 sebesar 0,73. Dari kedua pernyataan tersebut menghasilkan standar deviasi sebesar 0,79 atau sama dengan 15,8\%, angka tersebut tidak melebihi $20 \%$ dari mean. Maka diindikasikan ada keragaman jawaban indikator store theatrics atau sebagian besar responden menjawab dengan tanggapan yanghampir sama.

\section{Indikator Ketersediaan Waktu:}

Tabel 5: Tanggapan Responden Indikator Ketersediaan Waktu

\begin{tabular}{|c|l|c|c|}
\hline No. & \multicolumn{1}{|c|}{ Pernyataan } & $\begin{array}{c}\text { Rata-rata } \\
\text { (Mean })\end{array}$ & $\begin{array}{c}\text { Std. } \\
\text { Deviasi }\end{array}$ \\
\hline 1 & Saya memiliki banyak waktu untuk berbelanja (time10) & 2,85 & 1,07 \\
\hline 2 & $\begin{array}{l}\text { Saya bisa pergi lebih dari setengah hari hanya untuk } \\
\text { berbelanja (time11) }\end{array}$ & 3,49 & 1,26 \\
\hline 3 & $\begin{array}{l}\text { Saya menyempatkan diri untuk berbelanja sesibuk apapun } \\
\text { saya (time12) }\end{array}$ & 2,74 & 1,19 \\
\hline \multicolumn{2}{|l|}{ Rata-rata IndikatorKetersediaan Waktu } & 3,03 & 1,17 \\
\hline
\end{tabular}

Pada indikator ketersediaan ada tiga pernyataan, ketiga pernyataannyamemiliki total mean sebesar 3,03 (lihat tabel 5) hal ini membuktikan bahwa indikator ketersediaan waktu berada pada kategori cukup tinggi. Artinya sebagian besar konsumen memiliki waktu yang cukup banyak untuk berbelanja sehingga peluang melakukan pembelian tidak terencana pun cukup tinggi karena konsumen bisa menghabiskan waktunya di dalam toko. 
Standar deviasi yang diperoleh lebih dari $20 \%$ dari mean,maknanya keragaman jawaban untuk indikator ketersediaan waktu adalah besar atau sebagian besar responden menjawab dengan tanggapan yang agak berbeda.

\section{Indikator Ketersediaan Uang}

Tabel 6: Tanggapan Responden Indikator Ketersediaan Uang

\begin{tabular}{|c|l|c|c|}
\hline No. & \multicolumn{1}{|c|}{ Pernyataan } & $\begin{array}{c}\text { Rata-rata } \\
\text { (Mean) }\end{array}$ & $\begin{array}{c}\text { Std. } \\
\text { Deviasi }\end{array}$ \\
\hline 1 & $\begin{array}{l}\text { Saya memiliki uang lebih untuk melakukan } \\
\text { pembelian pakaian yang tidak direncanakan } \\
\text { (money14) }\end{array}$ & 3,28 & 1,14 \\
\hline 2 & $\begin{array}{l}\text { Saya memiliki anggaran khusus setiap bulan untuk } \\
\text { membeli produk fashion (money15) }\end{array}$ & 2,71 & 1,07 \\
\hline \multicolumn{2}{|l|}{ Rata-rata IndikatorKetersediaan Uang } & 3,00 & 1,10 \\
\hline
\end{tabular}

Pada indikator ketersediaan uang ada dua pernyataan, kedua pernyataan memiliki total mean sebesar 3,00. Hal ini membuktikan bahwa indikator ketersediaan uang berada pada kategori cukup tinggi. Artinya sebagian besar konsumen memiliki uang yang cukup banyak untuk berbelanja sehingga peluang melakukan pembelian tidak terencana pun cukup tinggi atau konsumen merasa memiliki fasilitas utama yang lebih dalam melakukan kegiatan berbelanja.

Standar deviasi yang diperoleh lebih dari 20\% dari mean yaitu sebesar $22 \%$ artinya ada keragaman jawaban untuk indikator ketersediaan waktu atau sebagian besar responden menjawab dengan tanggapan yang berbeda.

\section{Indikator Informasi dan Pengalaman}

Tabel 7: Tanggapan Responden Indikator Informasi dan Pengalaman

\begin{tabular}{|c|l|c|c|}
\hline No. & \multicolumn{1}{|c|}{ Pernyataan } & $\begin{array}{c}\text { Rata-rata } \\
\text { (Mean })\end{array}$ & $\begin{array}{c}\text { Std. } \\
\text { Deviasi }\end{array}$ \\
\hline 1 & $\begin{array}{l}\text { Saya akan membeli produk dengan merek yang } \\
\text { sama jika saya merasa puas dengan produk } \\
\text { tersebut sebelumnya (experience16) }\end{array}$ & 3,92 & 0,91 \\
\hline 2 & $\begin{array}{l}\text { Saya sudah mengetahui informasi tentang } \\
\text { merek produk yang saya beli berdasarkan } \\
\text { pengalaman pribadi (experience17) }\end{array}$ & 4,04 & 0,90 \\
\hline \multicolumn{2}{|l|}{ Rata-rata IndikatorInformasi dan Pengalaman } & 3,98 & 0,76 \\
\hline
\end{tabular}

Pada indikator Informasi dan Pengalaman terdapat dua pernyataan, kedua pernyataan menghasilkan total mean sebesar 3,98 hal tersebut membuktikan bahwa indikator informasi dan pengalaman berada pada kategori tinggi. Artinya sebagian besar konsumen membeli produk berdasarkan pengalaman dan informasi yang telah didapatkan sebelumnya, hal ini merupakan faktor yang mendorong konsumen mau melakukan pembelian tidak terencana.

Standar deviasi yang diperoleh tidak lebih dari 20\% dari meanatau sebesar 15,2\% menunjukkan variansi yang kecil, maknanya responden memiliki keragaman jawaban untuk indikator informasi dan pengalaman atau sebagian besar responden menjawab dengan tanggapan yang hampir sama. 


\section{Indikator Kredibilitas, Daya Tarik dan Kekuatan Kelompok}

Tabel 8: Tanggapan Responden Indikator Kredibilitas, Daya Tarik dan Kekuatan Kelompok

\begin{tabular}{|c|l|r|c|}
\hline No. & \multicolumn{1}{|c|}{ Pernyataan } & $\begin{array}{c}\text { Rata-rata } \\
\text { (Mean })\end{array}$ & $\begin{array}{c}\text { Std. } \\
\text { Deviasi }\end{array}$ \\
\hline 1 & $\begin{array}{l}\text { Saya tertarik membeli produk dengan merek } \\
\text { terkenal (reference18) }\end{array}$ & 3,72 & 0,92 \\
\hline 2 & $\begin{array}{l}\text { Saya mendapatkan rekomendasi suatu produk } \\
\text { dari orang-orang yang saya kenal } \\
\text { (reference19) }\end{array}$ & 3,66 & 0,9 \\
\hline 3 & $\begin{array}{l}\text { Saya tertarik membeli produk fashion model } \\
\text { terbaru (reference20) }\end{array}$ & 3,75 & 0,98 \\
\hline $\begin{array}{l}\text { Rata-rata IndikatorKredibilitas, Daya Tarik dan } \\
\text { Kekuatan Kelompok }\end{array}$ & 3,71 & 0,93 \\
\hline
\end{tabular}

Pada indikator kredibilitas, daya tarik dan kekuatan kelompok terdapat tiga pernyataan ketiga pernyataan menghasilkan total mean sebesar 3,71 dengan mean 18,6\%. Ini membuktikan bahwa indikator kredibilitas, daya tarik dan kekuatan kelompok berada pada kategori tinggi dan konsumen menjawab dengan tanggapan yang relatif sama. Kesimpulan yang dapat ditarik adalah bahwa produk yang terkenal serta model terbarumerupakan faktor yang mendorong konsumen untuk melakukan pembelian diluar rencana mereka. Selain itu rekomendasi dari kerabat atau orang yang dikenal konsumen juga menjadikan hal tersebut faktor yang mendorong konsumen untuk melakukan pembelian tidak terencana.

\section{Indikator Sifat Produk yang Menonjol}

Tabel 9: Tanggapan Responden Indikator Sifat Produk Yang Menonjol

\begin{tabular}{|c|l|c|c|}
\hline No. & \multicolumn{1}{|c|}{ Pernyataan } & $\begin{array}{c}\text { Rata-rata } \\
\text { (Mean) }\end{array}$ & $\begin{array}{c}\text { Std. } \\
\text { Deviasi }\end{array}$ \\
\hline 1 & $\begin{array}{l}\text { Saya membeli produk fashion yang memiliki } \\
\text { asesoris tambahan (product21) }\end{array}$ & 2,9 & 1,02 \\
\hline 2 & $\begin{array}{l}\text { Saya membeli produk fashion yang unik } \\
\text { (product22) }\end{array}$ & 3,84 & 0,95 \\
\hline \multicolumn{2}{|l|}{ Rata-rata IndikatorSifat Produk yang Menonjol } & 3,37 & 0,98 \\
\hline
\end{tabular}

Pada indikator sifat produk yang menonjol terdapat dua pernyataan, kedua pernyataan memiliki total mean sebesar 3,37 atau indikator sifat produk yang menonjol berada pada kategori cukup tinggi dan diperoleh informasi bahwa produk yang memiliki asesoris tambahan serta produk yang unik memiliki peran yang cukup tinggi bagi pemicu pembelian tidak terencana.Standar deviasi yang diperoleh 19,6\% $(0,96)$, ini menunjukkan ada kesamaan pendapat tentang indikator dari produk yang menonjol atau ada keragaman persepsi konsumen tentang indikator ini.

Hasil pengukuran indikator setelah dirangking seperti terlihat pada tabel 10 dan gambar berikut dibawah ini: 
Tabel 10: Rata-rata Nilai Indikator

\begin{tabular}{|l|c|c|}
\hline \multicolumn{1}{|c|}{ Indikator } & Mean & SD \\
\hline Store Atmosphere & $\mathbf{4 , 0 0}$ & 0,73 \\
\hline Store Image & 3,98 & 0,98 \\
\hline Infor.\&Pengala. & 3,98 & 0,76 \\
\hline Store Theatrics & 3,94 & 0,79 \\
\hline Daya Tarik+Kel & 3,71 & 0,93 \\
\hline Pro.Menonjol & 3,37 & 0,98 \\
\hline Keters.Waktu & 3,03 & 1,17 \\
\hline Keters.Uang & 3,00 & 1,10 \\
\hline Rerata & $\mathbf{3 , 6 3}$ & $\mathbf{0 , 9 3}$ \\
\hline
\end{tabular}

Sumber: Hasil penelitian, 2014

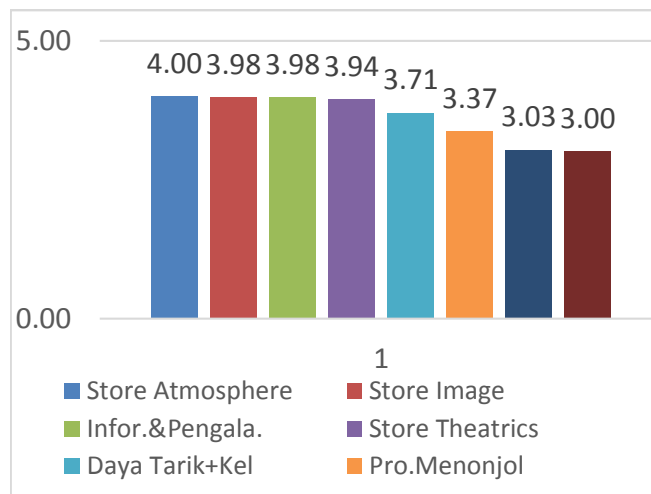

Gambar: Peringkat Indikator Impulsive Buying

Dari tabel 10 dan gambar grafik diperoleh informasi bahwa indikator store atmosphere memiliki nilai rata-rata tertinggi, kemudian diikuti oleh nilai store image dan seterusnya. Nilai rerata dari impulsive buying berada pada kriteria cukup $(3,63)$ mengarah kebaik. Makna yang bisa ditarik dari data ini adalah impulsive buying yang terjadi pada konsumen fashion di factory outlet kota Bandung dinilai oleh konsumen masih pada taraf cukup atau biasa-biasa saja dan belum mengalahkan akal sehat mereka untuk melakukan pembelian tanpa kendali. Hal ini disebabkan mayoritas responden berasal dari kalangan muda terdidik dan sebahagian besar mahasiswa.

\section{KESIMPULAN DAN SARAN Kesimpulan}

Berdasarkan uraian di atas tentang factor penentu yang menimbulkan perilaku Impulsive Buying konsumen factory outlet di kota Bandung, terdapat dua faktor penentu yaitu faktor yang berasal dari internal konsumen dan faktor yang berasal dari ekternal konsumen. Bagi pengusaha fashion membuat dan mengendalikan faktor ekternal lebih mudah dari pada faktor yang ada dalam diri konsumen. Beberapa factor penentu yang dapat menyebabkan pembelian tidak terencana tersebut yaitu:

1. Faktor ekternal terdiri dari store atmosphere, store image, store thatrics, daya tarik kelopok, produk yang menonjol. Sedangkan faktor yang berasal dari dalam diri konsumen seperti: informasi dan pengalaman yang dirasakan konsumen, ketersediaan waktu dan ketersediaan dana dari konsumen untuk melakukan pembelian.

2. Store atmosphere merupakan indikator dengan nilai tertinggi dari keseluruhan indikator yang ada. Store atmosphere pada FO di kota Bandung berada pada kategori "Tinggi" atau sudah baik. Kenyamanan lingkungan toko yang diciptakan pemilik toko secara langsung memberikan dampak yang positif terhadap pembelian tidak terencana konsumen FO di kota Bandung. Store atmosphere yang menarik adalah yang mampu menarik perhatian dan memberikan rasa nyaman pada lima panca indera manusia yaitu penglihatan, penciuman, pendengaran, peraba serta perasa.

3. Indikator ketersediaan uang memiliki tingkatan paling rendah dari semua indikator yang ada. Hal ini dapat disebabkan oleh latar belakang demografi responden yang sebagian besar adalah kalangan mahasiswa/pelajar dengan uang saku yang terbatas.

\section{Saran}

1. Penelitian ini perlu dilanjutkan dan diharapkan lebih mengarah kepada konsumen yang sudah memiliki pendapatan sendiri dengan ruang lingkup yang lebih luas. 
2. Kepada pengelola bisnis, untuk meningkatkan penjualan sebaiknya lebih memperhatikan indikator-indikator yang menjadi pembahasan pada penelitian ini seperti

a. Lingkungan Toko, ciptakan suasana toko yang nyaman serta berbeda dari pusat pebelanjaan lainnya. Dengan memberikan pelayanan yang prima disertai dengan situasi toko yang dapat memberikan pengalaman belanja konsumen lebih berbeda dari biasanya. Contohnya mengadakan hiburan-hiburan seperti pertunjukan seni untuk meningkatkan pengunjung.

b. Menambahkan variasi harga dari setiap kategori produk untuk memperluas target pasar.

c. Promosi-promosi yang dapat menarik perhatian konsumen, seperti iklan di media televisi ataupun media cetak. Serta memberikan diskon untuk produk dengan kriteria tertentu.

\section{DAFTAR PUSTAKA}

Abdullah, T., \& Tantri. 2012. Manajemen Pemasaran. Jakarta: Raja Grafindo Perkasa.

Asterrina, F., \& Hermiati, T. 2013. Pengaruh Discount Terhadap Perilaku Impulse Buying. Jakarta: Universitas Indonesia.

Azizah, T. N. 2015. Analisis Efisiensi Manajemen Data Pegawai Data Pegawai Melalui EOffice di Kantor Daerah Operasi 2 Bandung PT Kereta Api Indonesia (Persero). Bandung: Politeknik Negeri Bandung.

I'sana, A. D. 2013. Analisis Pengaruh Display Produk, Promosi Below The Line, dan Emosi Posirtif Terhadap Keputusan Pembelian Impulsif Pada Sri Ratu Pemuda Department Store. Semarang: Universitas Diponegoro.

Iyer, E. S. (1989), Unplanned purchasing: Knowledge of shopping environment and time pressure. Journal of Retailing, 65(1), 40-57

Fraenkel, J. \& Wallen, N. 1993. How to Design and Evaluate Research in Education. (2nd ed). New York: McGrawHill Inc

Muruganantham, G., \& Bhakat, R. S. 2013. A Review of Impulse Buying Behavior. International Journal of Marketing Studies, V, 149-157.

Nielsen Company. 2011. Pebelanja Makin Impulsif. Diambil dari www.antaranews.com/berita/264056/nielsen-pebelanja-makin-impulsif

Padmono. (2011). Evaluasi Pengajaran. Surakarta: UNS.

Park, E. J., Kim, E. Y., \& Forney, J. C. (2006). A structural model of fashion-oriented impulse buying behavior.

Putra, B. P. 2014. Analisis Pengaruh Promosi, Emosi Positif dan Store Environment Terhadap Perilaku Impulsive Buying. Semarang: Universitas Diponegoro.

Journal of Fashion Marketing and Management, 10(4), 433-446.

http://dx.doi.org/10.1108/13612020610701965

Santoso. 2007. Soal-Jawab Statistik dengan SPSS dan Excel. Jakarta: PT. Gramedia.

Schiffman dan Kanuk. 2008. Perilaku konsumen. Edisi 7. Jakarta: Indeks.

Sianturi, E., Erida, \& Nifita, A. T. 2012. Pengaruh Kelompok Referensi dan Gaya Hidup

Terhadap Keputusan Menggunakan Blackberry. 127-136.

Sugiyono. 2012. Metode Penelitian Kombinasi. Bandung: Alfabeta. . 2014. Metode Penelitian Kuantitatif Kualitatif dan $R \&$ \& Dandung: Alfabeta.

Sunyoto, D. 2015. Perilaku Konsumen dan Pemasaran. Jakarta: CAPS.

Suprapto, R. P., Saryadi, \& Shinta , R. 2015. Pengaruh Store Image dan Store Atmosphere

Terhadap Impulse Buying. Semarang: Universitas Diponegoro. 
Tenadidjaja, R. Y. (2007). Analisis Hubungan Perilaku Remaja Terhadap Pembelanjaan Impulsif Dengan Metode Structural Equation Model (SEM). Jakarta: Universitas Katholik Indonesia Atma Jaya.

Utami, C. W. (2010). Manajemen Ritel: Strategi \& Implementasi Operasional Bisnis Ritel Modern di Indonesia (2nd ed.). Jakarta: Salemba.

Verplanken, B., \& Herabadi, A. (2001). Individual Differences in Impulse Buying Tendency: Feeling and No Thinking. European Journal of Personality, S71-S83.

Yu, C., \& Bastin, M. (2010). Hedonic shopping value and impulse buying behavior in transitional economies: A symbiosis in the Mainland China marketplace. Journal of Brand Management, 18(2), 105-114. http://dx.doi.org/10.1057/bm.2010.32 